\title{
CLOUD-BASED ACCOUNTING SOFTWARE: CHOICE OPTIONS IN THE LIGHT OF MODERN INTERNATIONAL TENDENCIES
}

\author{
Yuliia Popivniak ${ }^{1}$
}

\begin{abstract}
The development of information technology combined with globalization, standardization, and proliferation of services based on the use of the Internet, and personal economic sanctions against some Russian software vendors in Ukraine made the search for new effective alternatives to existing programs among accounting cloud services extremely urgent. The purpose of the article is to study the international experience of cloud accounting software use, its strengths and weaknesses, threats and opportunities and to develop approaches to the choice of cloud services at the enterprises. The methodology which was used for analysing the advantages and disadvantages of implementing accounting software based on cloud technologies is SWOT analysis. The method of evaluating alternatives when choosing software provides for simultaneous comparison of its cost and a set of functional and technical characteristics. Results. Practically for all types of activities, the indicators of using cloud accounting services in Ukraine as in many other Eastern European countries (Poland, Greece, Bulgaria, Latvia, Romania, Hungary, etc.) lag behind the average European (31 countries analysed), and the worst situation is observed in the spheres of information and communications, professional, scientific, technical and real estate activities. Investing in the use of cloud products is at a low level due to their downsides related to privacy, trust, control, and data security. The choice of a cloud service or a cloud service provider must take into account the size of the enterprise, the volume of workflow, the number of employees, the forms of organization of accounting system, as well as the key service characteristics that we focus on in the article. Practical implications. Analysis and the right choice of cloud-based accounting software lead to the undeniable benefits for an enterprise (cost savings, convenience, mobility, etc.). This makes it possible to use the services, which are much cheaper than analogues, and most adapted to the conditions of business operations in a particular country. It also allows deepening the list of criteria for the choice of accounting software that would meet the needs of an individual enterprise. Value/ originality. Research data of the state and features of the application of accounting cloud services provide a better understanding of the current trends in their development and the place of Ukrainian enterprises among the leaders and outsiders in the international market for the users of such services.
\end{abstract}

Key words: cloud accounting, Internet, accounting software, international experience, cloud services.

JEL Classification: M41, 033, 057

\section{Introduction}

The rapid development of information technologies in conjunction with the global processes of standardization, globalization, increasing competition, the spread of services based on the use of the Internet, is increasingly raising the issue of activating the implementation of cloud technologies in enterprises, because these technologies are a source of growth and innovation, allow not only accumulating and storing information about the economic activities of the enterprise but also carrying out its processing and analysis, solving many problems the accounting system is facing.

Despite some threats of using cloud technologies, there are obvious cost savings in their acquisition and

\footnotetext{
Corresponding author:

${ }^{1}$ Ivan Franko National University of Lviv, Ukraine.

E-mail: bylja@ukr.net

ORCID: http://orcid.org/0000-0001-7458-0587
}

maintenance. The strengths of cloud services are the increased efficiency of accounting work, the flexibility, ease of access and simplicity of use, the ability to work with large volumes of information, the problem of protection of which is today very acute and confirmed by the numerous cyberattacks that have recently taken place in Ukraine and in the world. In this case, according to many scholars and practitioners, information is more protected from unauthorized access in the "cloud".

The peculiarity, which determines the urgency of researching the topic of choosing cloud-based accounting software products in Ukraine, is the introduction of personal special economic sanctions 
against Russian suppliers of these products (1C LLC, Parus Corporation LLC, Galaxy Center CJSC). The outlined trend points to the need for a gradual abandonment of Russian software products, which is currently used by a significant number of Ukrainian enterprises, and the search for new effective alternatives. In so doing, relevant is the study and consideration of international trends, the achievements of science and the practice of accounting with the use of cloud technologies in countries where their development has reached the highest level.

The current paper aims to study the international experience of using cloud software products in accounting to formulate approaches to the selection of their best possible options at the actual stage of economic activity. The object of consideration is the accounting software of the enterprise based on cloud services, and the tasks are:

1) carrying out a comparative analysis of indicators of the state of use of cloud services for accounting at Ukrainian enterprises and enterprises of other Eastern and Western European countries;

2) identification of opportunities, threats, strengths and weaknesses of the introduction of accounting software based on cloud technologies;

3) developing a methodology for selecting the best cloud accounting services among existing alternatives, taking into account the world experience.

\section{Brief literature review}

In recent years, the number of economic publications devoted to the use of cloud technologies (in particular, in accounting) is increasing. However, most of the information is found in technical literature, market research, or journalistic articles. Among the Ukrainian scientists who considered this problem, we distinguish I. F. Aulov, I. D. Horbenko, V. I. Hrytsenko, S. F. Legenchuk, T. V. Lytvynova, M. P. Pavlyukovets, O. A. Ursatyev, V. Frolov, M. O. Shchurovska, O. V. Yanovska, and others.

At the international level, the general principles of cloud computing (the conceptual-categorical apparatus, key characteristics and categories of the cloud computing service, their roles, types of capabilities, deployment models, cross-cutting aspects) are defined in International Standard ISO/ IEC 17788: 2014 (E) (International Organization for Standardization / International Electrotechnical Commission, 2014). The listed aspects are also covered by the Organisation for Economic Co-operation and Development (Organisation for Economic Cooperation and Development, 2014), National Institute of Standards and Testing (United States Department of Commerce) (Mell, Grance, 2011) and in the works of numerous researchers (Vacca, 2017; Rountree, Castrillo, 2014; Marinescu, 2013).
A lot of attention is devoted to the study of the features of the application of cloud services in accounting. So, X. Tang, Ch. Yan \& Y. Kang rightly argue that the choice of software is the main problem of the automated form of its maintenance (Tang, Yan, Kang, 2013). At the same time in the modern world, enterprises do not need to own servers or buy software for their installation on their own computers (Ebenezer, Omane-Antwi, Kyei, 2014). It is more profitable to use accounting systems based on cloud technologies, which provide a way of keeping records completely online and providing customers with on-demand services (Christauskas, Miseviciene, 2012). Making forecasts about the development of the accounting profession, M. Galarza believes that for the accounting service of the future, it is important to switch to cloud software, which will provide her with a strong statement and opportunities that were not available earlier (Galarza, 2017).

When deciding on the choice of an accounting cloud product, we take into account its strengths and weaknesses, risks and prospects for use. These issues have been studied in the scientific papers of many scientists (Ebenezer, Omane-Antwi, Kyei, 2014; Özdemir, Elitaş, 2015; Dimitriu, Matei, 2014, 2015).

Some scientists and practitioners wrote about the methodology of selecting accounting cloud services (Asatiani, Penttinen, 2015; Dimitriu, Matei, 2014; B. Ionescu, I. Ionescu, Bendovschi, Tudoran, 2013; Needleman, 2017; Christauskas, Miseviciene, 2012). A. Adhikari, M. I. Lebow \& H. Zhang focused on such a technique in an international context, taking into account the characteristics of the enterprise (size and level of internationalization), international functions (multicurrency, multireporting, and multilingualism) and the main selection criteria (support and security, hardware and operating platforms, flexibility and cost) (Adhikari, Lebow, Zhang, 2004).

Despite numerous studies, in modern scientific literature, the issues of applying accounting software based on cloud technologies are not fully covered, especially in Ukrainian realities. There is a lack of publications on comparative analysis of accounting cloud services on various grounds, as well as domestic programs and their foreign equivalents. The problem is the analysis of statistical data on the use of cloud computing, as in Ukraine the information in this section of the recently was not formed separately. Only since 2016 a new methodology for the organization and conduct of state statistical observation "Use of information and communication technologies in enterprises" has been applied.

Undisclosed are the issues of exploring opportunities and providing recommendations on the choice of accounting cloud services by the enterprises that are at the stage of demand formation and accumulation of experience of using cloud technologies by foreign companies. 


\section{International experience}

\section{of cloud-based accounting software use}

Researchers call the period from 2010 to this day the stage of "mobile" accounting software, which is based on the Internet and mobile applications that meet all the requirements of consumers (B. Ionescu, I. Ionescu, Bendovschi, Tudoran, 2013). Starting from 2013, the virtual stage in the development of information support is continuing, which means the spread of virtual workplaces and cloud technologies (which, however, began to be applied in large enterprises in the early 2000s (Vacca, 2017; Marinescu, 2013)) (Pavlyukovets, 2014).

In Ukraine, only $5.57 \%$ of enterprises that use the Internet connection, purchased in 2016 cloud software for financial and accounting purposes, while to the network have access up to $93.5 \%$ (average percentage for EU countries is 7\% and 97\%, respectively). The leaders in terms of Internet possibilities use and, in particular, the proportion of purchased accounting cloud services in Europe are Finland (26\%), Norway (22\%), and Sweden (21\%), as evidenced by the results of the comparative analysis of relevant statistics data (Figure 1).

As can be seen from Figure 1, among the 31 countries analysed, Ukraine ranks the 18th, with the leader
(Finland) ahead of it by 4,66 times. There is also a noticeable tendency in countries with better indicators of the use of accounting cloud services that they are applied primarily in small and medium-sized enterprises, while in lagging countries - in large ones. In Ukraine, the highest percentage of software usage based on cloud technologies is at large enterprises $(6.7 \%)$, while for medium and small enterprises it is $5.9 \%$ and $5.4 \%$ respectively.

Only in manufacturing and construction, the percentage of Ukrainian enterprises, acquired cloud services for financial and accounting needs, is higher than the average for EU countries (Figure 2). For all other activities, Ukraine lags behind the average European indicators, with the worst situation being in the information and communication sectors $(2,4$ times lagging behind), professional, scientific, and technical activities (2,1 times lagging behind), real estate activities (lagging behind in 1,8 times). The leader in almost all type of activities in Europe in 2016 is Finland (exceptions - Sweden's first place in transportation and storage and Norway's - in professional, scientific, and technical activities).

In 2017, the world's largest cloud infrastructure service providers were Amazon Web Services (34\%),

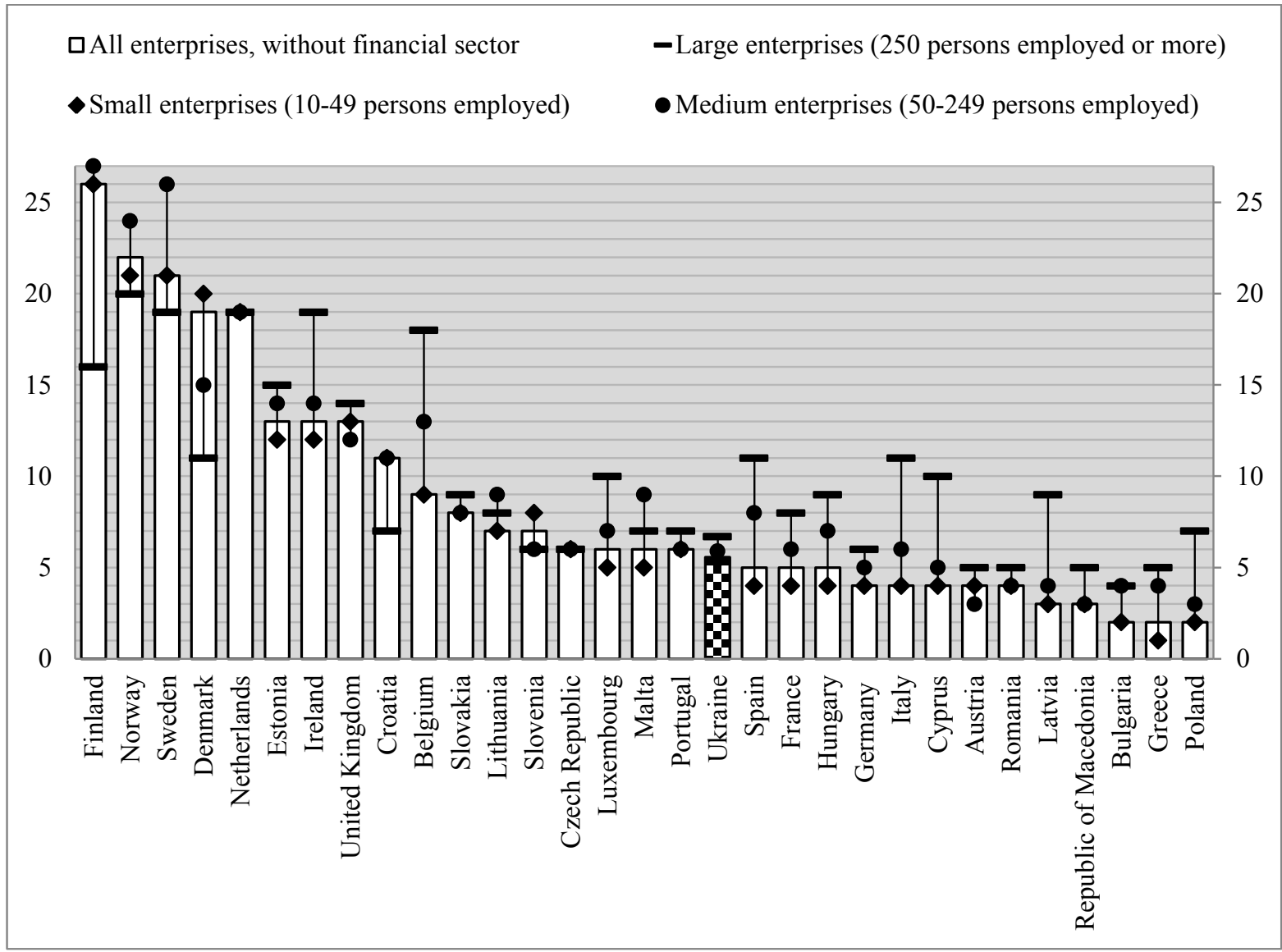

Figure 1. Share of enterprises that bought finance/accounting cloud software applications in the total number of enterprises with Internet access in 2016, \%

Source: compiled by the author according to (State Statistics Service of Ukraine, 2017; Eurostat, 2017) 


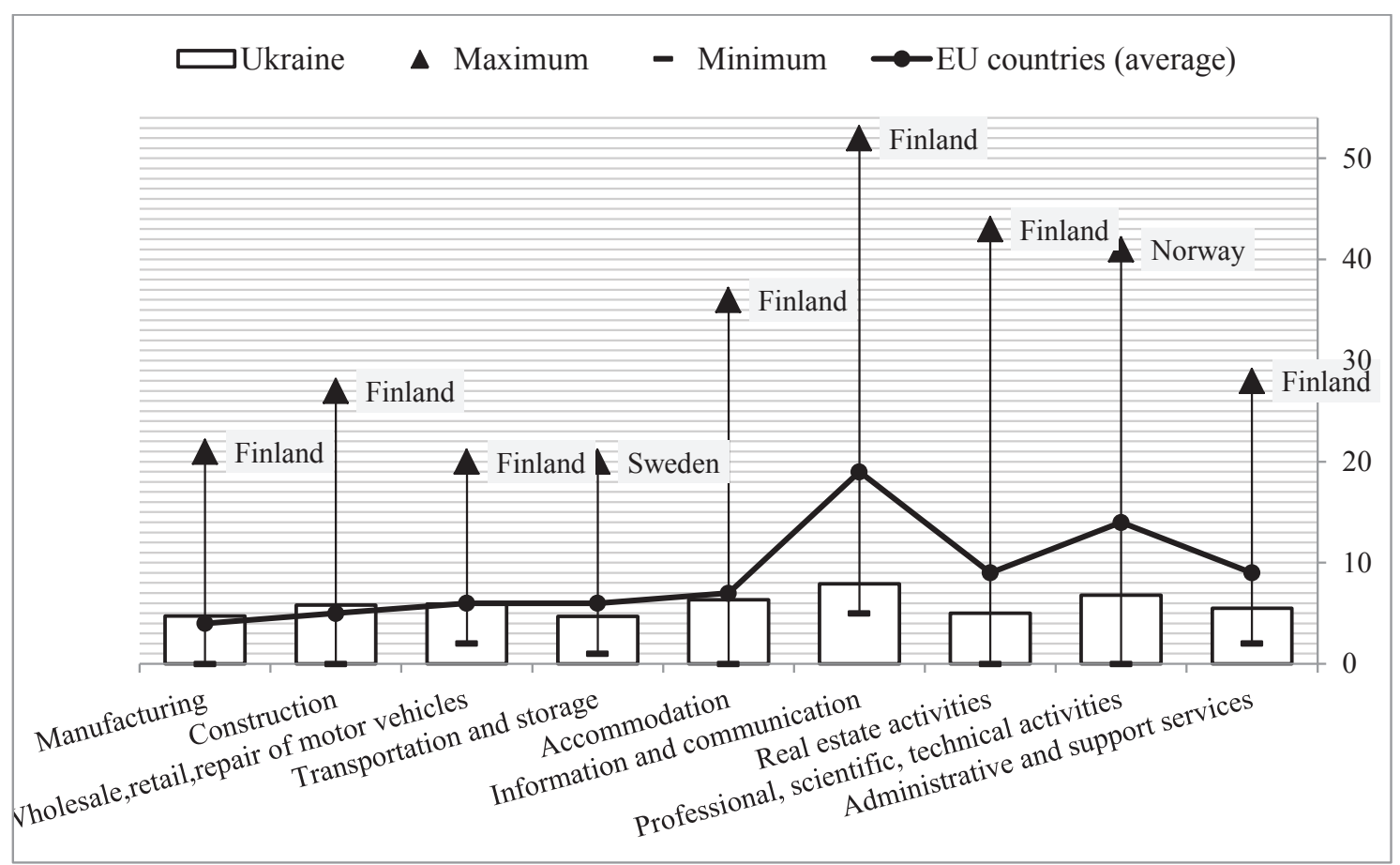

Figure 2. Ukraine's place among the leading European countries by the share of enterprises that purchased finance/accounting cloud software applications, by the types of activities in 2016, \%

Source: compiled by the author according to (State Statistics Service of Ukraine, 2017; Eurostat, 2017)

Microsoft (13\%), IBM (8\%), Google (6\%), and Alibaba (4\%) (Statista, 2018). According to Clutch 2017 Annual Cloud Computing Survey (Panko, 2017), 48\% of the world's IT companies plan to increase their investments in cloud computing by $11-30 \%$ and $14 \%$ - by $31-50 \%$ compared to the previous year (49\% of the enterprises surveyed want to make significant investments in Software as a Service (SaaS) and 38\% - in Infrastructure as a Service (PaaS) (Statista, 2018)). In many countries of Eastern Europe, investing in the acquisition of cloudbased software products for accounting purposes is not too common. We should find out the reasons for this phenomenon, the possible risks and disadvantages of using such software, in order to eliminate them and take advantages of its implementation.

\section{Cloud-based accounting software implementation: strengths, weaknesses, opportunities, and threats}

Before choosing the software, the enterprise should answer the question of its full readiness to exploit cloud technologies, the feasibility of their implementation in comparison with the programs that are already in use, the possibilities of transforming the accounting system into a more effective one. The most important strength of these technologies is the possibility of saving money, especially beneficial for small and mediumsized enterprises that do not need expensive and oversaturated with functions programs.
Particular attention should be paid to the weaknesses and threats of using cloud accounting services that relate to privacy, trust, control (Figure 3). Among other things, Ukrainian enterprises are characterized by problems of legislative regulation, prejudices related to a lack of knowledge (both in the choice of accounting cloud products, and the skills of using them), and the low level of information security.

According to some studies in the cloud environment, the level of security is higher than in the traditional one, and $45 \%$ of the surveyed IT professionals consider security to be the main advantage of cloud services (Rountree, Castrillo, 2014; Panko, 2017). We agree with the rule: who wants to expose the accounting information to the greatest risk, accumulates it in one place (Lehenchuk, Lozynskyy, 2014). According to PwC data, in 2017 cybercrime took second place in the world among all economic crimes ( $46 \%$ of enterprises suffered, what is $14 \%$ more than in the previous year). In so doing, the highest percentage of cybercrimes was typical for financial services (41\%) and the losses, as their result, cost some companies over 100 million dollars (PwC, 2018).

In Ukraine, the level of cybercrime in 2017, compared to 2016, was 3,1 times higher, and in the first three months of 2018 reached already $31.3 \%$ a year earlier (Prosecutor General of Ukraine, 2018). Obviously, in the Ukrainian realities, data security is a challenge to the implementation of accounting cloud services, especially in a hybrid war with Russia, one of the tools of which is precisely cyberattacks. 


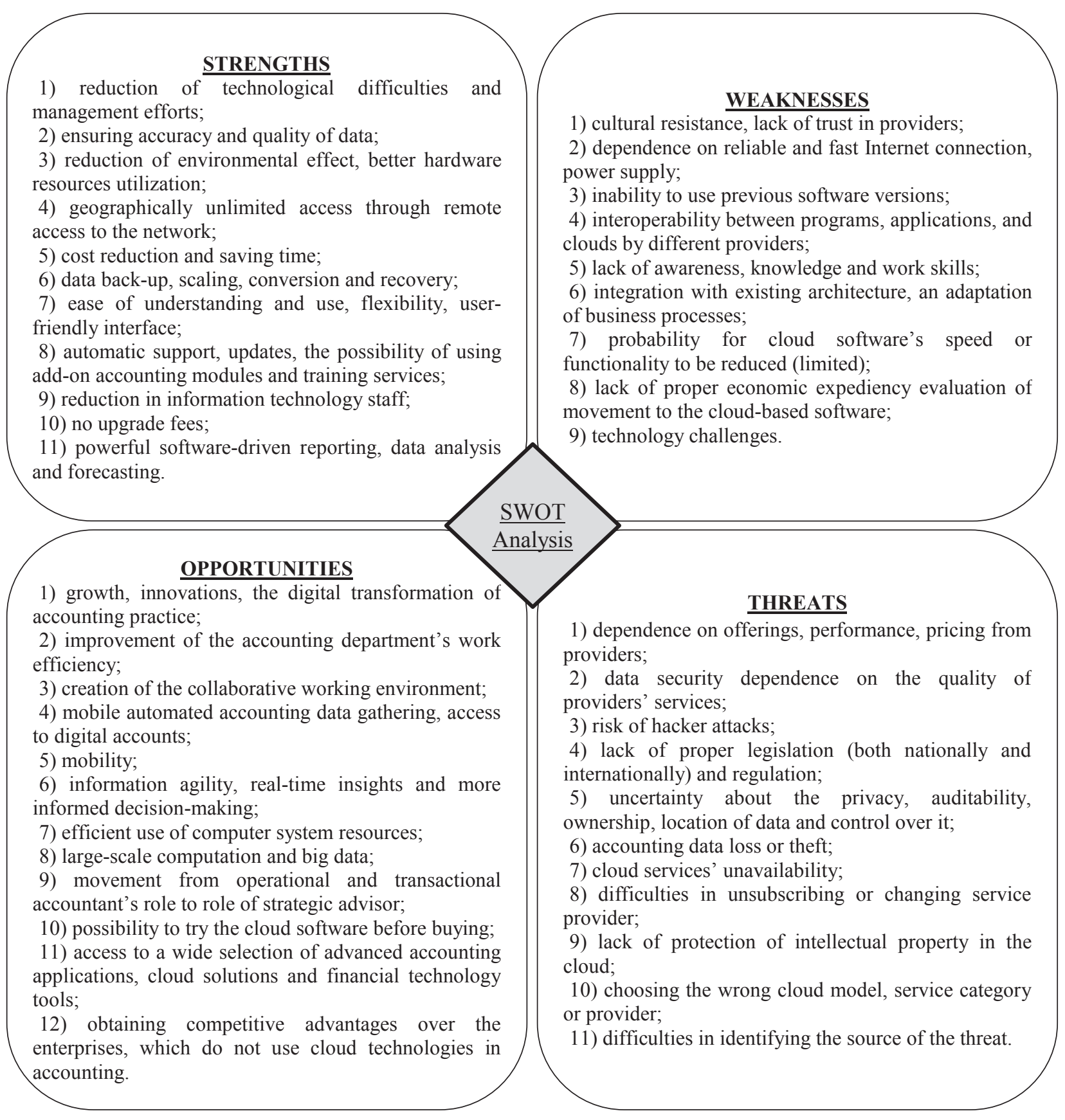

Figure 3. SWOT Analysis of cloud-based accounting software implementation at enterprises

Source: developed by the author

\section{Method of the accounting cloud services selection}

It is important that accounting, based on cloud technologies, is realized more as a service, and not as a product (Dimitriu, Matei, 2015). This is confirmed by the Ukrainian practice of economic activity, where payment for the use of cloud services is a payment for services in the field of informatization (although due to imperfections in legislation it can be mistakenly recognized as royalties, and services themselves as telecommunication services). The tariffication unit may be the number of users, records in the database, the amount of network traffic, processed data and transactions, the operating time of the user applications. Payment includes also the cost of maintenance, updates, and data protection. At the same time, a threat is the wrong choice of a cloud service or a cloud service provider by not taking into account the size of the enterprise, the volume of workflow, the number of employees, the forms and principles of an accounting system policy-making, and important requirements for the technical and functional characteristics of programs that we will focus on. 
C. Christauskas \& R. Miseviciene distinguish the following main functions of accounting information systems: data collection and storage, provision of information, provision of control, and forecasts of the future (Christauskas, Miseviciene, 2012), and C. S. Kent, R. A. Milligan \& W. A. Knoblauch examine three criteria for selecting accounting programs fundamental characteristics, features and outputs (Kent, Milligan, Knoblauch, 1985). A. Asatiani \& E. Penttinen highlight sales, purchases, payments, reporting, and payroll as groups of tasks that accounting software must perform (Asatiani, Penttinen, 2015).

Taking into account the peculiarities of accounting software in the "cloud", approaches in the processed literature and data from the site Capterra, which accumulates the world experience of using accounting software for more than 500 thousand professional users (Capterra, 2018), a rating of the 10 most popular and affordable programs is formed (from 201, using cloud services) (Table 1 ).

The rating construction methodology assumes integration of 14 of cloud-based accounting software main functional characteristics (Accounts Payable, Accounts Receivable, Bank Reconciliation, Billing and Invoicing, CPA Firms Accounting, Expense
Tracking, Fixed Asset Management, Fund Accounting, Government Accounting, Nonprofits Accounting, Payroll Management, Project Accounting, Purchase Orders, Tax Management), $40 \%$ of the total evaluation of the popularity of the cloud service is the number of customers, $40 \%$ - the number of users, and $20 \%-$ social score. The algorithm for determining the rating by the criterion of affordability requires consideration of the cost of software, the number of features offered, and the average customer review score.

As we can see, most foreign cloud products are designed for the needs of small and medium-sized enterprises. At the same time, the use of programs of such well-known in Ukraine vendors as SAP, Oracle or Microsoft is not cheap. It should also be taken into consideration that they do not take into account the economic and legislative peculiarities of the work of Ukrainian enterprises; therefore, they need additional costs for modification and adaptation. In such circumstances, it is advisable to consider the proposals of domestic developers of accounting cloud services (Figure 4).

Comparing the average price of the service (since the cost often varies depending on the package of services offered by the provider) in US dollars equivalent according to the National Bank of Ukraine rate and the

Table 1

Rating of the most popular and affordable cloud accounting software in October 2018

\begin{tabular}{|c|c|c|c|c|c|c|c|c|}
\hline \multirow[b]{2}{*}{ Rank } & \multicolumn{4}{|c|}{ Most popular software } & \multicolumn{4}{|c|}{ Most affordable software } \\
\hline & $\begin{array}{l}\text { Accounting software } \\
\text { (vendor) name }\end{array}$ & $\begin{array}{l}\text { Number } \\
\text { of features } \\
\text { supported } \\
\text { (max. 14) }\end{array}$ & $\begin{array}{l}\text { Price (per } \\
\text { user / per } \\
\text { month), \$ }\end{array}$ & $\begin{array}{l}\text { Main } \\
\text { clients }\end{array}$ & $\begin{array}{l}\text { Accounting software } \\
\text { (vendor) name }\end{array}$ & $\begin{array}{l}\text { Number } \\
\text { of features } \\
\text { supported } \\
\text { (max. 14) }\end{array}$ & $\begin{array}{l}\text { Price (per } \\
\text { user / per } \\
\text { month), } \$\end{array}$ & $\begin{array}{l}\text { Main } \\
\text { clients }\end{array}$ \\
\hline 1 & $\begin{array}{l}\text { QuickBooks } \\
\text { (Intuit Inc., USA) }\end{array}$ & 11 & $\begin{array}{l}5,00- \\
30,00\end{array}$ & $\mathrm{SE}^{1}, \mathrm{SB}^{2}$ & $\begin{array}{l}\text { Accounting by Wave (Wave } \\
\text { Financial Inc., Canada) }\end{array}$ & 14 & free & SE, SB \\
\hline 2 & $\begin{array}{c}\text { FreshBooks (FreshBooks Inc., } \\
\text { Canada) }\end{array}$ & 3 & $\begin{array}{c}15,00- \\
50,00\end{array}$ & SE, SB & $\begin{array}{c}\text { Reckon One } \\
\text { (Reckon Ltd., Australia) }\end{array}$ & 11 & $5,00-30,00$ & SB, MB \\
\hline 3 & $\begin{array}{l}\text { Accounting by Wave (Wave } \\
\text { Financial Inc., Canada) }\end{array}$ & 14 & free & SE, SB & $\begin{array}{l}\text { Odoo Accounting } \\
\text { (Odoo S.A., Belgium) }\end{array}$ & 14 & 14,00 & $\begin{array}{l}\text { SE, SB, } \\
\text { MB, LB }\end{array}$ \\
\hline 4 & $\begin{array}{l}\text { Microsoft Dynamics } 365 \\
\text { (Microsoft Corp., USA) }\end{array}$ & 13 & $\begin{array}{l}40,00- \\
210,00\end{array}$ & $\begin{array}{c}\mathrm{SE}, \mathrm{SB}, \\
\mathrm{MB}^{3}, \mathrm{LB}^{4}\end{array}$ & $\begin{array}{c}\text { Easy Accountax } \\
\text { (Easy Accountax, UK) }\end{array}$ & 12 & $2,40-15,00$ & SE, SB \\
\hline 5 & $\begin{array}{c}\text { Xero } \\
\text { (Xero Ltd., New Zealand) }\end{array}$ & 14 & $\begin{array}{c}27,50- \\
75,00\end{array}$ & SB, MB & $\begin{array}{l}\text { SimpleBooks (GoSimple } \\
\text { Software Ltd., UK) }\end{array}$ & 5 & 6,00 & SE, SB \\
\hline 6 & $\begin{array}{l}\text { Oracle Financials Cloud } \\
\text { (Oracle Corp., USA) }\end{array}$ & 5 & 600,00 & $\begin{array}{l}\text { SE, SB, } \\
\text { MB }\end{array}$ & $\begin{array}{c}\text { Xero } \\
\text { (Xero Ltd., New Zealand) }\end{array}$ & 14 & $\begin{array}{c}27,50- \\
75,00\end{array}$ & $\mathrm{SB}, \mathrm{MB}$ \\
\hline 7 & $\begin{array}{c}\text { Sage Business Cloud } \\
\text { Accounting } \\
\text { (Sage Group plc, UK) }\end{array}$ & 8 & $\begin{array}{c}10,00- \\
25,00\end{array}$ & SE, SB & $\begin{array}{c}\text { Zoho Books } \\
\text { (Zoho Corp. Pvt. Ltd., India) }\end{array}$ & 8 & $2,90-4,50$ & $\begin{array}{l}\text { SE, SB, } \\
\text { MB }\end{array}$ \\
\hline 8 & $\begin{array}{l}\text { Odoo Accounting } \\
(\text { Odoo S.A., Belgium })\end{array}$ & 14 & 14,00 & $\begin{array}{l}\text { SE, SB, } \\
\text { MB, LB }\end{array}$ & $\begin{array}{c}\text { Billy } \\
\text { (Billy US Inc., USA) }\end{array}$ & 5 & $\begin{array}{c}15,00- \\
39,00\end{array}$ & SE, SB \\
\hline 9 & $\begin{array}{c}\text { Zoho Books (Zoho Corp. Pvt. } \\
\text { Ltd., India) }\end{array}$ & 8 & $2,90-4,50$ & $\begin{array}{l}\text { SE, SB, } \\
\text { MB }\end{array}$ & $\begin{array}{c}\text { Smarty (Smarty software Ltd., } \\
\text { UK) }\end{array}$ & 8 & $2,00-45,00$ & SB \\
\hline 10 & $\begin{array}{c}\text { Kashoo (Kashoo Inc., } \\
\text { Canada) }\end{array}$ & 9 & $\begin{array}{c}16,65- \\
29,95\end{array}$ & SE, SB & Officewise (Officewise, USA) & 13 & $0,00-8,95$ & $\begin{array}{l}\text { SE, SB, } \\
\text { MB, LB }\end{array}$ \\
\hline
\end{tabular}

${ }^{1}$ - self-employed; ${ }^{2}$ - small businesses, ${ }^{3}$ - medium businesses, ${ }^{4}$ - large businesses

Source: developed by the author according to (Capterra, 2018) and information on the official websites of software vendors 


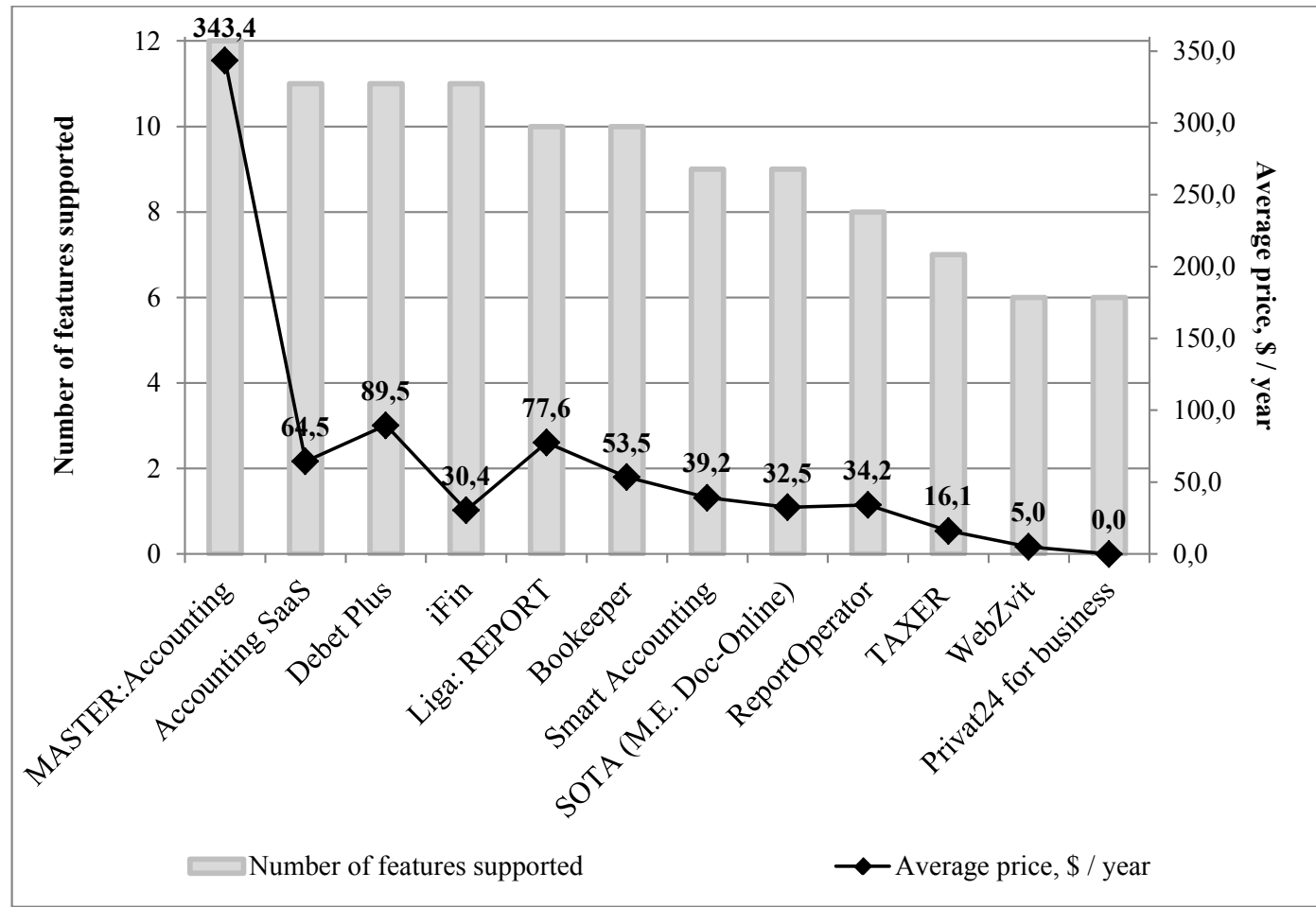

Figure 4. Comparison of the main Ukrainian cloud-based accounting software as of October 2018

Source: developed by the author according to information on the official websites of software vendors

minimum set of functions that accounting software must perform at the Ukrainian enterprise (tax accounting; reporting; databases of registers, directories; electronic workflow; electronic primary documents; integration with other software; ease of modification; data security; bank accounts management; job management/payroll; version for mobile phone; demo version; consolidation of reporting, updates and support), we note the superiority of Master:Accounting over other programs in terms of functionality, but the biggest disadvantage of this software is its high price. More popular and affordable is, for instance, SOTA (from the developer of accounting software M.E.Doc), but its weak side is the low level of data security. Thus, when choosing a cloud service for accounting, all factors should be weighed on the basis of the needs of a particular enterprise.

Should also not be excluded such additional factors as the provider's reputation, the availability of a free trial period, guarantees, telephone and web support, purchase discounts, user-friendly interface, the possibility for program to grow together with the enterprise and the needs of its customers.

\section{Conclusions}

The conducted research of features of a choice of accounting cloud services on the basis of the international experience of their use provides grounds for the following conclusions.
1. The level of application of cloud technologies for accounting purposes in Ukraine as in most Eastern European countries remains today below the average European indicator for almost all types of activities. At the same time, the gap between the best practices, which are concentrated in the Scandinavian countries, ranges from 3,4 times to 8,6 times.

2. When choosing software products, all their advantages and additional features (cost savings, convenience, increase of the efficiency of the accounting service, mobility) should be compared with weaknesses and threats, especially related to privacy, trust, and data security.

3. Nowadays in the world, there are many cloud computer programs, different in cost, functional and technical capabilities. However, they do not take into account the national peculiarities of the business operations, which in Ukraine are related to the search for reasonably priced products, the need for parallel tax accounting, enhanced data security, etc. Therefore, we recommend promoting the improvement and development of domestic cloud services, based on the best practices for developing and using them in the USA, Canada, UK, Australia, etc., by introducing such services at Ukrainian enterprises. Expanding the analysis tools according to the size of an enterprise, its type of activity, and other additional conditions for choosing software, we consider this to be the focus of further research. 


\section{References:}

Adhikari, A., Lebow, M. I., Zhang, H. (2004). Firm characteristics and selection of international accounting software. Journal of International Accounting, Auditing \& Taxation, 13, 53-69.

Asatiani, A., Penttinen, E. (2015). Managing the move to the cloud - analyzing the risks and opportunities of cloud-based accounting information systems. Journal of Information Technology Teaching Cases, 5, 27-34.

Capterra (2018). Accounting Software. Retrieved from: https://www.capterra.com/accounting-software/\# affordable (accessed 11 October 2018).

Christauskas, C., Miseviciene, R. (2012). Cloud-Computing Based Accounting for Small to Medium Sized Business. Engineering Economics, 23(1), 14-21.

Dimitriu, O., Matei, M. (2015). Cloud accounting: a new business model in a challenging context. Procedia Economics and Finance, 32, 665-671.

Dimitriu, O. A., Matei, M. (2014). New Paradigm for Accounting through Cloud Computing. Procedia Economics and Finance, 15, 840-846.

Ebenezer, E. E. Sh., Omane-Antwi, K. B., Kyei, M. E. (2014). Accounting in the Cloud: How Cloud Computing Can Transform Businesses (The Ghanaian Perspective). Proceedings of the Second International Conference on Global Business, Economics, Finance and Social Sciences (GB14Chennai Conference). Chennai.

Eurostat (2017). Cloud computing services. Retrieved from: http://appsso.eurostat.ec.europa.eu/nui/ show.do?dataset=isoc_cicce_use\&lang=en (accessed 25 September 2018).

Galarza, M. (2017). The changing nature of accounting. Strategic Finance, 2, 50-54.

International Organization for Standardization / International Electrotechnical Commission (2014). Information technology - Cloud computing - Overview and vocabulary: International Standard 17788:2014(E). Geneva.

Ionescu, B., Ionescu, I., Bendovschi, A., Tudoran, L. (2013). Traditional accounting vs. cloud accounting. Proceedings of the Accounting and Management Information Systems - AMIS 2013. Bucharest. Retrieved from: https://www.researchgate.net/publication/267751382_TRADITIONAL_ACCOUNTING_VS_CLOUD_ ACCOUNTING (accessed 20 September 2018).

Kent, C. S., Milligan, R. A., Knoblauch, W. A. (1985). Criteria for and evaluation of selected on-farm accounting software. New York: Cornell University.

Lehenchuk, S. F., Lozynskyy, D. L. (2014). Idealjna systema bukhghaltersjkogho obliku: utopichna ideja chy realjnistj IT-ekonomiky? [Ideal accounting system: the utopian idea or reality of the IT economy?]. Accounting and Auditing, 2, 3-11. (in Ukrainian)

Marinescu, D. C. (2013). Cloud Computing Theory and Practice. Waltham: Elsevier Inc.

Mell, P., Grance, T. (2011). The NIST Definition of Cloud Computing. Recommendations of the National Institute of Standards and Technology. Gaithersburg: Information Technology Laboratory.

Needleman, T. (2017). Re-evaluating your tax software? Our 2017 comparison guide lays out the packages side by side. Accounting Today, 8, 24-26.

Organisation for Economic Co-operation and Development / Directorate for science, technology and industry Committee on Digital Economy Policy (2014). Cloud Computing: the Concept, Impacts and the Role of Government Policy: DSTI/ICCP(2011)19/FINAL. Paris: OECD Publications.

Özdemir, S., Elitaş, C. (2015). The Risks of Cloud Computing in Accounting Field and the Solution Offers: The Case of Turkey. Journal of Business Research-Türk, 7/1, 43-59.

Panko, R. (2017). How Businesses Use Cloud Computing: 2017 Survey. Retrieved from: https://clutch.co/cloud/ resources/annual-cloud-computing-survey-2017(accessed 25 September 2018).

Pavlyukovets, M. P. (2014). Koncepcija pobudovy suchasnoji systemy obliku na siljsjkoghospodarsjkomu pidpryjemstvi $\mathrm{v}$ umovakh internet-tekhnologhij [Concept of construction a modern accounting system of the agricultural enterprise in the conditions of internet technologies]. Accounting and Finance, 2(64), 66-70. (in Ukrainian) Prosecutor General of Ukraine (2018). Vidomosti pro zarejestrovani uprodovzh 2017 roku zlochyny u sferi vykorystannja elektronno-obchysljuvaljnykh mashyn (kompjuteriv) ta rezuljtaty jikh rozsliduvannja [Information about registered during 2017 crimes in the field of computers and the results of their investigation]. Kyiv. Retrieved from: https://dostup.pravda.com.ua/request/statistika_kibierzlochinnosti_v_3 (accessed 25 September 2018). (in Ukrainian) PwC (2018). Pulling fraud out of the shadows. Global Economic $\bar{C}$ rime and Fraud Survey 2018. USA: PwC.

Rountree, D., Castrillo, I. (2014). The Basics of Cloud Computing: Understanding the Fundamentals of Cloud Computing in Theory and Practice. Waltham: Elsevier Inc.

State Statistics Service of Ukraine (2017). Vykorystannja informacijno-komunikacijnykh tekhnologhij na pidpryjemstvakh. Statystychnyj bjuletenj [Use of information and communication technologies at enterprises. Statistical bulletin]. Kyiv. (in Ukrainian)

Statista (2018). «As a Service» cloud model investment plans for next 1-3 years - IT leaders worldwide, as of 2017. Retrieved from: https://www.statista.com/statistics/662804/worldwide-cio-survey-cloud-service-investmentplans/ (accessed 28 September 2018).

Statista (2018). Global market share of cloud infrastructure services in 2017, by vendor. Retrieved from: https://www.statista.com/statistics/477277/cloud-infrastructure-services-market-share/ (accessed 26 September 2018). Tang, X., Yan, Ch., Kang, Y. (2013). The Internal Control of Computerized Accounting in Information Era. In B.Xu. (Ed.), Proceedings of the 2012 International Conference on Information Technology and Management Science (ICITMS 2012). Berlin: Springer-Verlag Berlin Heidelberg.

Vacca, J. R. (Ed.) (2017). Cloud computing security: foundations and challenges. Boca Raton: CRC Press. 